\title{
Educating a New Generation of Students
}

Transferring knowledge and norms from Hong Kong to the mainland

\section{Amy Liu Mei Heung and David Zweig}

\section{OpenEdition \\ Journals}

\section{Electronic version}

URL: http://journals.openedition.org/chinaperspectives/6110

DOI: 10.4000/chinaperspectives.6110

ISSN: 1996-4617

\section{Publisher}

Centre d'étude français sur la Chine contemporaine

\section{Printed version}

Date of publication: 15 March 2013

Number of pages: 73-86

ISSN: 2070-3449

\section{Electronic reference}

Amy Liu Mei Heung and David Zweig, "Educating a New Generation of Students », China Perspectives [Online], 2013/1 | 2013, Online since 01 March 2016, connection on 28 October 2019. URL : http:// journals.openedition.org/chinaperspectives/6110; DOI : 10.4000/chinaperspectives.6110 


\title{
Educating a New Generation of
}

\section{Students}

\author{
Transferring knowledge and norms from Hong Kong to the mainland
}

\author{
AMY LIU MEI HEUNG AND DAVID ZWEIG
}

\begin{abstract}
All Hong Kong universities have been actively influencing education in China since 1997. The major methods include: running an independent university in one case, and managing and transforming four colleges in another; training many mainland students in Hong Kong who upon graduation return there; and serving as a home base on the doorstep of the mainland from which academics can influence their colleagues across the border. This paper shows how all these methods transfer a new set of academic norms prevalent in Hong Kong to the mainland. ${ }^{(1)}$
\end{abstract}

KEYWORDS: international education, returned scholars, overseas students, value transfer.

F oreigners have tried for centuries to change China, but as many studies have shown, it is no easy task. (2) Chinese organisations and norms resist external pressures for change, as many key players feel far more comfortable with traditional modes of interaction and the existing distribution of power and authority. Reforming Chinese academic institutions has always been difficult, ${ }^{(3)}$ particularly in the post-1978 era, ${ }^{(4)}$ because the Chinese state sees universities as the core institution that keeps Chinese youth loyal to the dominant value system and the existing political structures. Education's responsibility is also to socialise a citizenry, unify the country ideologically, and prepare high calibre leaders to reconcile communist precepts with market economics. ${ }^{(5)}$

Yet, as this paper shows, since 1997 and the reversion of Hong Kong's sovereignty to China, the former British colony, and today's Special Administrative Region, has been at the forefront in transferring more universal values to the mainland, in large part through its academic institutions. This transfer has occurred in three major ways: (1) by creating new academic institutions on the mainland, which transfer new modes of thought and more liberal values to students and administrators in areas such as media, politics, medical delivery, and legal training; (2) by training mainland students in Hong Kong's universities who return to teach and work on the mainland; and (3) allowing mainlanders trained in Hong Kong and the West to "park" on the mainland's "doorstep" in Hong Kong's freer intellectual environment, from which they can transfer some Western values and research methodologies into the mainland.

This paper addresses these three modes through case studies and survey data.

\section{Foreign institutions taking root in a Chinese environment: Two paths}

China's late Premier Zhao Ziyang believed that reforms could best succeed in China only by creating what he called "small environments" (xiao huanjing) of reform. While macro-efforts at change would confront serious op- position from conservative forces in the leadership, if micro-models of successful reform could demonstrate their effectiveness, they might motivate others to adopt similar policies or programs. The effort to build Special Economic Zones during the reform era was based on this viewpoint. ${ }^{(6)}$ This perspective matches the Chinese Communist Party's (CCP) policy on policy experimentation and "test points." (7) While success could be copied, failure would have limited impact. ${ }^{(8)}$ Yet as Heilmann outlines, the key question is "how to facilitate institutional change despite massive inertia and opposition that block structural reform and inhibit economic development in many political economies, without trying to impose foreign blueprints and thereby ignoring the intricacies of local conditions." (9)

1. Parts of this paper appeared in two issues of Xinbao caijing yuekan (Hong Kong Economic Journal Monthly). See "Gang gui pai: xuezi huiguo diaocha - Xiang Gang ban jiaoyu chanye huode haoping" (Returnees from Hong Kong: A Survey of Returning Students - Hong Kong's Education Industry Gets a Good Evaluation), No. 393, December 2009, pp. 6-15; and "Xiang Gang zuowei neidi jiaoyu de chuangkou," (Hong Kong as an educational window for domestic education), No. 381, December 2008, pp. 10-16.

2. Jonathan D. Spence, To Change China: Western Advisers in China, 1620-1960, New York, Penguin Books, 1980; and Randall E. Stross, The Stubborn Earth:American Agriculturalists on Chinese Soil, 1898-1937, Berkeley (CA), University of California Press, 1986.

3. Marianne Bastid, "Servitude or Liberation? The Introduction of Foreign Educational Practices and Systems to China since 1840," in Ruth Hayhoe and Marianne Bastid (eds.), China's Education and the Industrialized World: Studies in Cultural Transfer, Armonk (NY), M. E. Sharpe, 1987.

4. Zhang Weiying, Daxue de luoji (The logic of the university), Beijing, Peking University Press, Second Edition, 2006. Zhang led the failed reform of Beida in 2003.

5. Wing-Wah Law, "Citizenship, citizenship education, and the state in China in a global age," Cambridge Journal of Education, Vol. 36, No. 4, 2006, pp. 597-628.

6. Joseph Fewsmith, Dilemmas of reform in China: Political conflict and economic debate, Armonk (NY), M.E. Sharpe, 1994, and Ezra Vogel, Deng Xiaoping and the Transformation of China, Cambridge (MA), Belknap Press of Harvard University Press, 2011

7. Sebastian Heilmann, "Policy Experimentation in China's Economic Rise," Studies in Comparative International Development, Vol. 43, No. 1, January 2008, pp. 1-26; and Sebastien Heilmann, "From local experiments to national policy: The origins of China's distinctive policy process," The China Journal, No. 59, January 2008.

8. David Lampton (ed.), Policy Implementation in Post-Mao China, Berkeley, University of California Press, 1987, Introduction.

9. Sebastian Heilmann, "Policy Experimentation in China's Economic Rise," op. cit., p. 26. 
Antithetically, the diffusion of innovation literature argues that new organisations must be compatible with existing norms; otherwise they will be difficult to replicate. ${ }^{(10)}$ However, if the new organisation posits no new norms or organisational values, offering little that is new to the local community, why take the time and undergo the effort of bringing in change?

How does one build these "small environments?" Should one create a totally new institution, which, while internally coherent, may be isolated from, or attacked by, society or outside organisations whose values it challenges? Or, should one reform an existing institution that is already embedded in Chinese society, but face the possibility that opponents of reform remaining within the organisation struggle against the new norms that are being introduced? (11) The two universities discussed below followed these two strategies in their efforts to change China's education system.

Although the Li Ka-shing Foundation (LKSF) founded Shantou University in 1991, Hong Kongers made little effort in the early years to influence the school's management. Only after the infusion of a major donation in 2002 were Hong Kongers invited to join the school and introduce reforms, making Shantou University (STU) an example of outsiders changing an existing institution from within. The second case, the United International College (UIC), reflects Hong Kong Baptist University's (HKBU) efforts to create a new, independent institution in China whose success might become a model for other institutions. ${ }^{(12)}$

\section{Transforming Shantou University: The power of Hong Kong's purse}

The LKSF is one of Hong Kong's most active organisations working to improve the quality of education on the mainland. As of 2008, it had spent the massive sum of US\$8.4 billion - 62 percent in the mainland, 11 percent overseas, and 37 percent in HK. Donations focused on healthcare (42 percent) and education (46 percent) because Li Ka-shing's father died of TB when Li was quite young - the family could not afford a doctor - and poverty prevented Li from receiving an education. ${ }^{(13)}$

The Hong Kong advisors working at STU claim major success in innovating programs and administrative procedures in the university following the massive infusion of funds in 2002. ${ }^{(14)}$ Sounding like former Chinese reform leader Zhao Ziyang, Li Ka-shing, in a personal letter, asked the Chinese government for special policies to create a "small university but a huge platform." Since then, the LKSF has become "a catalyst for constructive changes," and an "engineer of educational reform." (15)

Reforms changed four colleges, all run by Hong Kongers - three advisors reside in Hong Kong and fly up weekly, while one, who was born in Hong Kong but taught in Australia, lives in Shantou. The programs are the Law School, the Journalism School, the Design School, and the Medical School.

Borrowing from the program at The Chinese University of Hong Kong (CUHK), the medical school has the most distinctive curriculum in the mainland. A five-year undergraduate program was introduced in 2002, but most students take a seven-year MA. The program is very practical, with students going to hospitals beginning in the second semester of their first year. They also work in the countryside in groups of 18-20 students.

STU's Medical College (SUMC) established a program in hospice care for cancer patients in 20 cities across China, with mobile vans and small offices where they receive terminally ill cancer patients. With the Chinese University of Hong Kong, the college also created turnkey cataract surgery clinics - a decision initiated by Li Ka-shing himself - as cataracts involve little post-surgery care and the recovery process can be monitored by phone. The medical school has five teaching hospitals in Shantou, and the school is planning a program for hospital and public health administrators.

The university's provost, a mainlander who worked at The University of Calgary for 20 years, was keen to transform the university both from inside and from the bottom up, so he empowered the faculty by entrenching a participatory system. "To transform a university and move it from stage to stage, you need a system of governance and quality programs, and this exists in Hong Kong." (16) Yet he acknowledges strong resistance. "The best universities have excellent staff, alumni, students, finances, and reputation, and the people have a voice," but the Chinese side at STU "just doesn't get it, they don't understand the importance of due process, of equity, and the need to make it fair." This is a problem common to many Chinese universities.

A key question was the locus of institutional power. After 20 years in a democratic Canada, the Provost was committed to transferring authority from the university's Communist Party Secretary to the faculty. No doubt, such a major change was facilitated by the fact that he controlled so much of the university's budget. And although the Communist Party Secretary claimed to be very open-minded, the VP told him that "when I am finished with my work, you will have less power." A Faculty Senate with an Education Committee, an Academic Discipline Committee, and a Graduate Committee were all established under faculty control. Policies cannot be changed at the whim of the President or the Party Secretary, and faculty members, not the administrators, form the majority of Senate members.

However, as with most outside aid, sustainability is a major problem. The main solution, the VP argued, was to get the administrators to buy into the new policies.

We are very conscious of "sustainability"; we always talk about how to leave a footprint behind. So we try to institutionalise the changes and change the mindset of the people we work with in China and the students... You need the locals to buy into the program, to work with you, so you need to give them incentives to leave their traditional culture behind. Sometimes we change the people, not just the way they think, because we need to get them to follow us. ${ }^{(17)}$

Having deep pockets made this major transformation possible.

A major problem for foreign organisations in the mainland is the limited capabilities of local administrators who function at a level far short of their Hong Kong staff. Hong Kong universities are generally very well administrated at all levels. Anna Wu, advisor to the Law School, sees a paucity of

10. Everett M. Rogers, "Attributes of Innovations and their Rate of Adoption," in Everett M. Rogers (ed.), Diffusion of Innovation (5 $5^{\text {th }}$ ed.), New York, Free Press, 2003, pp. 219-66.

11. David Zweig, "Foreign Aid, Domestic Institutions, and Entrepreneurship: Fashioning Management Training Centres in China," Pacific Affairs, Vol. 73, No. 2, July 2000, pp. 209-32.

12. The research was collected through direct interviews and observations. Zweig and Liu visited UIC for two days of intensive interviews, while Zweig travelled to Shantou. The authors met teachers, staff, and top school officials, either when they visited Hong Kong or during campus visits. On both campuses, the authors held focus meetings with students and with faculty.

13. Anthony B. Chan, Li Ka-shing: Hong Kong's elusive billionaire, Toronto, Macmillan Canada, 1996.

14. Interview in Hong Kong with a senior administrator, STU, January 2009. The Foundation pledged another HK\$5.3 billion to support STU, of which HK\$3.6 billion had been donated as of 2010 . See www.lksf.org/en/project/education/stu (consulted on 11 October 2012).

15. Interview in Hong Kong with a senior administrator, STU, January 2009.

16. Interview with the Provost of STU in Hong Kong, 2009.

17. Interview with the Provost of STU in Hong Kong, 2009. 
well-trained people "who can work at the bottom to get things done and keep things continuing... As a result, it was necessary to strengthen the management, even the quality of departmental secretaries." (18)

Funding again played a critical role. The university sent most senior administrators to EMBA programs in China, including the Cheung Kong Graduate School, founded by Li Ka-shing. According to the VP, this training turned administrators into problem solvers rather than "naysayers." The university also invited McKinsey, the consulting firm, into the university to advise on improving the management.

With Hong Kong as a nexus, and with other overseas links, the university is highly "internationalised." Internationalisation is about new standards and norms, and having distinct features, and the LKSF gives reformers the power to push for these changes. Through the LKSF, the university has a network of collaborating universities outside the mainland, composed of other beneficiaries of the LKSF. One administrator who expressed a positive attitude towards these changes is the director of the Foreign Affairs Office, who recognises that while the reforms relied on these outsiders, the Chinese education system constrained reforms at STU.

It is hard to get permission to run joint programs, so though we want to do this, it is bureaucratically very complicated. So we run "dual degree" programs with the University of Toronto Medical School. Difficulties come from the Ministry of Education, but also the provincial government makes lots of difficult guidelines.

Under Hong Kong's influence, the Law School is carving out new terrain. While Anna Wu's expertise is in Common Law, she established a program in "alternative dispute resolution mechanisms," including arbitration, mediation, and negotiation skills, which is also a tool for cross-cultural training. "This is a good change for society. It is a pioneer program, accredited in HK by the International Arbitration Centre, and is the first one accepted by the mainland." In July 2007, the school graduated its first four undergraduate law students, who also received an MA in Common Law from Hong Kong University, allowing them to work for Hong Kong law firms, including Deacons and Baker Mackenzie.

The Law School's annual summer intern program introduces 10-12 students to Hong Kong's legal institutions. According to Wu, Hong Kong's experience pushes the students' minds to straddle the two systems.

Hong Kong is a huge incubation ground for opening their minds... They have to do a weekend of charity work, with legal aid or small claims court, or work in the Independent Commission against Corruption (ICAC), and a huge array of legal institutions.

Numerous indicators reflect the success of these efforts. The Law School's arbitration program is accredited by the Hong Kong International Arbitration and Mediation Association; in 2008, it was awaiting recognition from the United Kingdom's Chartered Institute of Arbitration. (19) In 2006, 14 of 30 graduate students and alumni passed the National Bar Exam on their first try, placing the Law School first in all of China. (The passing rate nationwide is around 15 percent.) One of the World Trade Organization Panel judges is from the STU Law School. As for the Medical College, in 2005, its students ranked third among 170 medical schools in the National Medical Licensing Exam, and in 2006, they were ranked fourth. They also won the second prize in the Higher Education Achievement Award.

\section{United International College}

United International College (UIC), a joint venture between Hong Kong Baptist University (HKBU) and Beijing Normal University (BJNU), is situated on the branch campus of BJNU in the Zhuhai Special Economic Zone in Guangdong Province. It is the first liberal arts college in China, and all classes are taught in English. Because its graduates receive an academic degree from HKBU (and a graduate certificate from the Ministry of Education in Beijing), the University Grants Committee under the Hong Kong Government must certify that UIC's academic programs meet Hong Kong standards, a fact certified in 2008. Unlike mainland universities, where students take 90 percent of their major courses in professional education, UIC has only a 50 percent requirement (10 percent less than $\mathrm{HKBU}$ ), making it a genuine liberal arts program.

According to UIC's current president, Ng Ching-fai, who was HKBU's president when UIC was established, the concept driving the college is "diversification." (20) In his view, mainland education is "too one-sided," an exam-oriented education system that in his words "is even more horrible than the one in Hong Kong." But because exams deliver some degree of equity, the MOE hesitates to replace it. So, reforming education in China necessitates diversifying the deliverers of education by inviting outside universities into China. By supplying only the land, mainland universities can import foreign expertise without any major expense. Other aspects of "diversification" include rules that faculty must attend campus daily and meet students regularly in their offices, something rare on the mainland. As in Hong Kong, the faculty runs committees, and the college's Senate, claims President $\mathrm{Ng}$, is the final repository of academic authority. Job searches are public, with departments responsible for their own hiring. Promotions are also controlled by the college, but there are no quotas on promotion from the Ministry of Education in Beijing.

According to President Ng, in 1997, during the Asian Financial Crisis, he proposed that Hong Kong universities should go "off-shore" into the mainland and export their teaching methods, rather than simply bringing mainland students to Hong Kong. Then Permanent Secretary for Education, Fanny Law, encouraged him. Yet he denies that HKBU is on the mainland for the money; the cost of faculty and facilities, such as libraries, makes it very hard to make a profit. Instead, he emphasises the great opportunity to expand HKBU's education platform. Also, HKBU could not use any budgetary funds allocated from the UGC, so it borrowed HK\$150 million from HKBU's "Continuing Education Fund," monies raised by teaching the Hong Kong community.

A sense of great opportunity infuses the senior administrators. Edmund Kwok Siu-tong, Executive Vice President, sees a huge demand from mainland students for education services provided by Hong Kong's universities.

There are 630,000 candidates from Guangdong who will be sitting the National Higher Education Entrance Examination this year and the number of places available at prestigious universities in the province can hardly meet their demand. ... Hong Kong's universities should strive to export their education services across the border, and running institutions on the mainland is an effective way to achieve the goal. (21)
18. Interview with Anna Wu Hung-yuk, Hong Kong, 2009.
19. Interview with a senior administrator of STU, December 2008.
20. Amy Liu's personal interview with President $\mathrm{Ng}$ Ching-fai.
21. Gary Cheung, "Grooming talent," South China Morning Post, 20 April 2009. 


\section{The locus of power}

A key issue for IUC was the role of the Chinese Communist Party (CCP) on campus. While the university, like other schools in China, must coordinate its programs with the MOE and the provincial education bureau, its president is not directly responsible to the Party Secretary of the university's CCP committee. In fact, there is no Party committee; and, according to President $\mathrm{Ng}$, the CCP's representative on campus has no real power. Originally, there was to be no CCP representative at all on campus, but UIC feared that without a CCP office, the MOE would suspect them of trying to go off on their own. Still, "If UIC was really led by the Party Secretary, why bother having the school? How different would we be from other mainland universities?" (22)

This situation, however, did not arise without a fight. As one professor recalled, the school had to ward off an effort to introduce an activist Party secretary. In spring 2005, BJNU sent two officials to the school, one as Registrar and one as a Vice President who was to be the Party secretary. However, no one informed the latter that he would not have real authority. Only when he attended his first Senate meeting, which was run entirely in English, a language he could not understand, did he realise that no one was yielding authority to him. Thereupon he insisted that, since he was the Party secretary, and the meeting could not be run without his full participation, it had to be run in Mandarin. At that point, President $\mathrm{Ng}$ reportedly took him aside and promised to summarise the meeting for him afterwards, allowing the meeting to proceed in English. When the Party secretary followed up with a letter to President Ng, insisting that the school should be run by the CCP's Party secretary, President Ng told BJNU that this man was unacceptable because he knew no English. He was replaced as Party secretary by the registrar, who plays a very low-key role, focusing mostly on the work of the Communist Youth League, of which most mainland students are members.

\section{Innovative programs}

Perhaps UIC's primary innovation is bringing Hong Kong's education system in its totality into China. According to one faculty member,

We have done well very quickly. The students' parents understood the advantage of teaching their children in English. Second, all teachers here teach; even top professors spend a lot of time with the students, unlike in mainland universities where the top professors are rarely in the classroom. Here, it doesn't matter how famous you are! (23)

A careful look at some programs shows innovations equal to those at STU. The department of Environmental Sciences has a major in International Organization for Standardization (ISO) training, With China's manufacturing so closely linked to the global market, there is a huge demand in the mainland for ISO auditors and inspectors. Yet apparently only the Ministry of Environmental Protection runs environmental assessment training programs through which people can gain accreditation for ISO, making UIC the first university on the mainland to run this program. A major benefit of this elective is accreditation and job placement. After completing their courses, students need only a two-week training course to be certified for ISO on the mainland. Also, due to the Combined Economic Partnership Agreement (CEPA), once mainland students complete the major and the Environment Assessment course, they can take the auditor's test in Hong Kong, the certificate of which will be accepted in both HK and the mainland.
Accounting is the hottest program at UIC. The Dean of the Business School, herself an accounting professor, has an excellent network in the region, allowing the school to organise top internships, excellent placements, a fine mentoring program, and world quality guest lectures. Students confirm the strength of this program: the Big Four accounting firms always recruit on campus, and since UIC professors have worked in Hong Kong, there are always jobs for the graduates. Knowing this, parents apparently push students to attend this program. In fact, unlike the students in International Journalism, who reported that UIC was not their first choice, Accounting was the first choice of most of the students we interviewed. Third, the program is well known in the Pearl River Delta (PRD), where firms recognise the value of the "Hong Kong Experience," which the students can get even though they studied in the mainland. Finally, students learn better presentation skills at UIC than at most other schools, largely because they are fluent in English, a language they need to get jobs in joint ventures or in Hong Kong.

The quality of the students' presentation skills was confirmed by their results in the Quality Program Case Competition run in Beijing by the HK Chartered Accountants Society. After coming second in 2009, they won the title in 2010, while a second Hong Kong team came in fourth. With the competition in English, UIC students have a great advantage.

In 2009, the Accounting Department at UIC was the first program on the mainland to be accredited by the Hong Kong Institute of Certified Public Accountants (HKICPA). Upon graduation, students are automatically offered membership in the HKICPA, and after working for three years and passing the Qualification Program exams, they can become HK Certified Public Accountants. The program had already qualified for CPA-Australia in 2007.

A focus group with students in both the Accounting program and the International Journalism program showed the extent of the normative change that some students had undergone. Talking to them, one gets the feeling of being on a college campus anywhere in the world, where students freely discuss and debate their viewpoints. As one student commented, "We have a higher level of tolerance for different opinions." Part of this attitude derives from HKBU's "Whole Person Education" (WPE) program, which includes courses in experiential learning, environmental awareness, emotional intelligence, adversity management, experiential development, university life, and sports culture. Students are also expected to engage in voluntary service to a community somewhere in the world, which ensures that they all have overseas experience.

However, in the words of one journalism student, extensive value change is a "double-edged sword," because after studying with foreign teachers in a free environment, students must rein in their new values if they wish to have a career in China's politically controlled media. One student worried that if she went overseas for graduate school, she would become "a political refugee," while another commented that before attending UIC, she was politically unaware, with no idea what June $4^{\text {th }}$ was all about. She had been, in her words, "living in a protected cage."

The journalism faculty recognises this conundrum. According to one professor, "We teach them that they are living in China in changing times, so they can choose to have pro-reform sentiments, but these views must be based on an analytical approach; they must understand the realm in which they live." Students understand this situation; as one commented: "If we

22. Interview with a senior faculty member, UIC, Zhuhai, March 2011.

23. Interview with senior faculty, UIC, Zhuhai, March 2011. 
work for a media company in China, we will have to adjust to the real situation, but in your mind, you know what the truth is."

In this way, just as foreign institutions must make some concessions if they wish to integrate somewhat into Chinese soil, individuals seeking success must do the same.

Students also have developed a global viewpoint. "Nearly all of us have an international perspective; we think independently and want to know something new and exciting." Some students planned to do the "Voluntary Service" component of Whole Person Education overseas, perhaps in Africa, as their parents can afford to send them abroad. Students scoffed at old high school friends who cannot understand why they would take an international internship "without getting paid."

\section{Problems with the external environment}

As a new foreign organisation treading on new ground in China, UIC confronts difficult times. A senior administrator observed, "The road forward has never been smooth," as bureaucratic rules, external government forces, and even UIC's joint venture partner, BJNU, seriously constrained UIC's daily activities. Some professors believe that the MOE no longer cares if the school succeeds. Even the official schoolbook, celebrating five years of UIC, states that "Despite special approval by the Ministry of Education, UIC faced difficulty in gaining acceptance since there was no precedent." An official from the MOE who visited in 2008 seemed to be hedging when he pointed out that UIC was "only a pilot program." (24)

In truth, problems arose early. Having received formal approval only in July 2007, UIC was initially given half a day to select its students from the roster of the national exam. Administrators contemplated deferring the opening another year, but instead went ahead - who knew what would happen the following year? Faced by this determination, the MOE extended the enrolment deadline by a few days. Similarly, when they wanted to establish the school as a Chinese "legal person" (faren), which would let it sign contracts with faculty and run its own affairs legally,

We were tossed around for six months. Everyone kicked the ball, not wanting to take responsibility. We wanted to start classes but we were not legal. So, HKBU had to hire all our faculty. Even when the school was officially opened in October 2005 we were still not legal. (25)

Promoting the faculty is problematic. The MOE stipulates how many full, associate, and assistant professors public Chinese universities can promote. But UIC gets no quota and determines the number on its own. Reportedly, Guangdong's Education Bureau objected to this situation, calling UIC a "phoenix" that had flown into China from overseas. Second, because UIC is a private university, other constraints arise. Although the college has close ties to the Fulbright Program office in Hong Kong, it cannot get a fulltime Fulbright scholar; the MOE reserves such positions for public universities directly under its authority. UIC's Government and International Relations Program therefore used the Fulbright Senior Specialist Program to bring in two people for six weeks each, and brought in Fulbright Scholars from Hong Kong each week for three-hour seminars.

Third, faculty members receive fewer benefits than professors at other universities in Zhuhai. All professors in Special Economic Zones (SEZs) receive a subsidy, because SEZs are more expensive than other parts of China. But the UIC faculty receives no such subsidies. Similarly, mainland citizens who return from abroad to teach, the so-called "sea turtles" (hai gui pai), receive better housing, education subsidies for their children, and access to start-up funds for their research; but UIC's "sea turtles" receive no such benefits. As one senior faculty member commented, "Because the government doesn't see us as their baby, we are real second class citizens."

UIC students do not get the same treatment as students in other mainland universities. UIC replaced its courses in Marxism-Leninism with courses on "national culture" (guo qing); however, students who have not taken courses in Marxism-Leninism cannot enter graduate school on the mainland. Ironically, if students pass the part of the Civil Service exam that assesses their knowledge of Marxism, they can still work for the Chinese government; but unless they take an official university course on Marxism, mainland graduate schools remain closed to them. As a result, a significant number of these talented liberal arts students apply for graduate school at HKBU or other graduate programs outside the mainland, which may be the MOE's goal. Still, it is China's loss if these students settle abroad.

Plans for close collaboration with BJNU did not bear fruit, and relations soured after UIC was established. Initially, half of the teaching faculty at UIC was to come from BJNU, but no BJNU faculty could teach well enough in English to meet UIC's standards. Second, UIC had planned to cut costs by relying on BJNU's library, but the limited space in the BJNU library forced UIC to build its own library. Finally, with BJNU's branch campus already accommodating 20,000 students, space is at a premium. BJNU now covets the UIC campus and reportedly looks forward to the end of their contract (which still has 25 years), when BNJU will get the land and facilities.

One idea being floated is to turn UIC into Zhuhai University. Should it become a local university within the Chinese education system, these external constraints might disappear. However, while many of the headaches of working within the mainland would disappear, what is unique about UIC would disappear as well.

\section{The future}

STU's experiment appears to have greater sustainability than UIB. The LKSF's deep pockets and the foundation's excellent reputation bolster this effort. Internal resistance apparently was overcome by the infusion of funding in 2003. Also, the external environment seems more benign, though both schools faced significant bureaucratic hurdles posed by the Guangdong Education Bureau and the Ministry of Education in Beijing. Thus, despite the view that transforming old institutions is more difficult than creating totally new small environments, the reform of STU by this group of Hong Kongers appears to have been quite successful. The Provost was able to change the university's internal governance significantly; worth noting is that both schools successfully constrained the university's Communist Party Secretary.

While funding for Shantou has not been a problem, the UIC experiment remains under a cloud due to financial difficulties. It pays 8 percent of its annual income to HKBU as loan repayment, 15 percent to BJNU as a branding fee and rent ( 5 and 10 percent respectively), (26) and another 50-60 percent as salaries, leaving little money for books and new equipment. As a result, tuition rises every year, reaching RMB 60,000 in 2011-2012. Unable

24. UIC $5^{\text {th }}$ Anniversary, Five Years of Exploration and Innovation, Zhuhai, United International College, 2010, p. 14.

25. Interview with a senior faculty member, UIC, Zhuhai, March 2011.

26. Vivian Kwok, "Colleges set aside mainland projects: Universities lose steam in cross-border race," South China Morning Post, 26 July 2010, pp. 1-2. 
Table 1 - Percentage of funds in key Hong Kongbased projects going to the mainland

\begin{tabular}{|l|c|}
\hline Percentage of Project Funds & Percent of Interviewees \\
\hline $100 \%$ & 17 \\
\hline $75-99 \%$ & 12 \\
\hline $50-74 \%$ & 14 \\
\hline $25-49 \%$ & 24 \\
\hline Less than $25 \%$ & 33 \\
\hline
\end{tabular}

Source: Interviews with mainlanders in Hong Kong, 2001-2, and 2004.

Note: $\mathrm{No}=51$, as some people had no projects or chose not to respond.

or unwilling to raise its salaries, UIC cannot get long-term commitments from its staff. Rules about tenure are opaque; final authority rests with top administrators who utilise this power rather independently. Similarly, many lower level administrators, who are locals, do not stay long, creating a gap in institutional memory that complicates the life of students and newly arrived faculty who need helpful advice.

Finally, leadership at UIC is more quixotic than at Shantou. In 2011, some faculty members were uneasy about the impending resignation of Vice President Kwok, whom they saw as the senior administrator with the most "vision." (27) They believed that President Ng, a member of the National People's Congress, and Vice President Zee, a member of the Chinese People's Political Consultative Conference (CPPCC), "lack commitment to a Liberal Arts format with foreign input." They see these two leaders as unwilling to take risks, or "push the boundaries of what is allowed." VP Kwok, on the other hand, often told faculty to proceed quietly with more innovative programs rather than ask for permission. As one faculty member commented, although "they can't get anything like UIC inside China," he worries that the commitment to Liberal Arts education at UIC is waning.

Nevertheless, the path chosen by HKBU is the one that foreign universities seeking to set up transnational programs or schools in China are following. Nottingham University has a campus in Ningbo, while Liverpool has established a collaborative university in Suzhou with the prestigious Xian Jiaotong University. The Americans are on their way, with New York University (NYU) creating a university campus in Shanghai. Ironically, while constraints in Hong Kong on how money from the University Grants Council can be used are forcing Hong Kong universities to reconsider plans to expand campuses on the mainland, ${ }^{(28)}$ the world seems to be moving in.

\section{Parking on the doorstep: Mainland academics in Hong Kong}

Mainland academics trained overseas have taken up a significant number of academic posts in Hong Kong universities, (22) as salaries, research facilities, funding, and academic freedom are greater in the territory than at any mainland universities. To investigate the involvement of this group in the mainland, Zweig and his research team carried out face-to-face interviews with 24 mainland academics who were working in Hong Kong. Then in 2004, using pinyin names, Zweig found 401 mainland academics who were teaching in Hong Kong, while Liu estimated that 450 such academics were teaching in Hong Kong's eight universities. ${ }^{\left({ }^{30}\right)}$ All 401 academics were sent an email asking them to participate in an online survey. Information from the 70 Mainlander professors who responded to the survey was com- bined with the original interviews in Hong Kong, creating the database for this study. ${ }^{(31)}$

Among this cohort, a majority had been in Hong Kong for over 10 years, of whom 47 percent were permanent residents. ${ }^{(32)}$ Most had been trained at top Western universities: of 41 for whom we have data, 8 studied at University of Toronto, four at Princeton, three at MIT, four at Columbia, five at the University of British Columbia, three at Ohio State, and four in the California system. Among these academics, 66 percent were full or associate professors (11 percent were full professors), 56 percent received their degree in the United States of America (USA), and another 19 percent had PhDs from Canada.

As senior academics, they engage actively with the mainland and attract good mainland graduate students. In fact, Hong Kong encourages collaborative projects among its academics and mainland scholars. The Research Grants Council and China's Natural Science Foundation (NSFC) offer grants promoting Hong Kong-mainland projects. As a result, significant amounts of research monies raised by Hong Kong academics go to the mainland (Table 1). One interviewee expressed a desire to spend most of his grant monies in China or on colleagues in China due to "sympathy for their situation. If you look at the breakdown of costs, we don't have to spend money on cross-Pacific flights, so more money can go into China." (33) Mainlanders in Hong Kong wanted to improve the research capabilities of their mainland colleagues. ${ }^{\left({ }^{34}\right)}$ Also, mainlanders interviewed in Hong Kong were becoming more and more involved in teaching, research, lecturing, and running conferences on the mainland. Most recently, under the "1000 Talents Plan" begun in 2008, more than a dozen mainlanders working in Hong Kong have become "1000 Talents Scholars," and under this program spend two to three months a year working on the mainland. ${ }^{(35)}$

The different rates of interaction of Hong Kong-based and US-based mainlanders (Table 2) show that Hong Kong-based academics were more involved with the mainland than the US-based respondents. (36) Using these six modes, we calculated the mean level of interactions, which for mainland academics in the US was 1.5 interactions versus 2.9 interactions for HKbased mainland scholars.

Clearly, proximity plays a major role, as Beijing and Shanghai are four and two hours from Hong Kong by plane, respectively. Moreover, the universities

27. "Prof. Edmund Kwok-a UICer at all times," http://uic.edu.hk/en/index.php?option=com_ content\&task=view\&id=1211\&ltemid=217 (consulted on 13 April 2011).

28. Vivian Kwok, "Colleges set aside mainland projects," art. cit.

29. Liu Mei-heung, Zhong Gang jiaoyu da ronghe: Bei shang nan xia (The integration of Hong Kong and China's education: Going north and coming south), Hong Kong, Ya dian wenhuan qiye youxian gongsi, 2007.

30. The research was carried out by Han Donglin, then a PhD student at HKUST, who is currently an Associate Professor at Renmin University in Beijing.

31. See David Zweig, "Parking on the Door Step," Center on China's Transnational Relations, Working Paper No. 3, HKUST, www.cctr.ust.hk/research/working_paper.html (consulted on 20 September 2012).

32. It is necessary to live in Hong Kong for seven years before applying for permanent residency status.

33. Zweig, "Parking on the Doorstep," art. cit.

34. Interview in Hong Kong with professor at HKUST, 2007

35. Interview in Hong Kong with professor at HKUST, May 2012. For an analysis of this plan, run by the Organisation Department of the CCP, see David Zweig and Wang Hui-yao, "Can China Bring Back the Best? The Communist Party Organizes China's Search for Talent," The China Quarterly (forthcoming).

36. In 2004, we found our US respondents by dividing American universities into three cohorts comprising 100 universities. They were subdivided based on the size of their endowment. We randomly selected 20 universities in each cohort, searched the web sites of these 60 universities for professors with "pinyin" names, and then asked them to participate in a web-based survey. Of 756 professors who were contacted by email, 94 responded. 
Table 2 - Modes of interaction with the mainland in Hong Kong and the US

\begin{tabular}{|c|c|c|}
\hline Modes & HK \% & U.S.\% \\
\hline Collaborative research with mainland scholars & 66.3 & 43.6 \\
\hline Run seminars or mini-courses in China & 67.3 & 48.9 \\
\hline Training mainland students & 63.3 & 29.8 \\
\hline Gave academic papers on the mainland & 38.3 & 17 \\
\hline Edited book with mainland scholars & 16.3 & 13.8 \\
\hline Consult with mainland or foreign companies on the mainland & 5.1 & 5.3 \\
\hline Total number of respondents & 98 & 94 \\
\hline
\end{tabular}

Source: Interviews with mainlanders in Hong Kong, 2001-2, and 2004. Mainlanders in the United States were surveyed in 2004.

Note: The score is the percent of faculty who selected that mode. People could select more than one mode.

in Hong Kong strongly encourage their faculty to work with mainland colleagues. Yet one must note that the web-based survey in the US was finished before the more recent academic China fever at many American universities.

\section{Training mainland students in Hong Kong}

On the eve of the transfer of sovereignty, Hong Kong academic officials were keen to harvest the student talent that existed on the mainland. Hong Kong parents, in general, did not encourage their children to select careers that were not financially lucrative, so quality research assistants in numerous fields were in high demand on Hong Kong's campuses, especially if one relied in large part on local students. Second, in 1997, mainland universities were far from world class; ${ }^{(37)}$ tens of thousands of students from China's top universities were embarking for the West for graduate training. ${ }^{(38)} \mathrm{De}$ spite concerns in Hong Kong that mainlanders would swamp local universities, therefore, university administrators decided to promote a strategy to bring more mainlanders to Hong Kong.

\section{An aborted student enrolment scheme, 1997-99}

On the eve of Hong Kong's transfer of sovereignty to China, some university administrators in Hong Kong were overzealous in their efforts to bring in mainland students. In order to protect Hong Kong from being swamped by mainland students, the procedures for getting a visa to study in Hong Kong were taking many months. Applicants accepted in the late spring or early summer, when final grades were announced on the mainland, could never arrive in time for the start of the fall semester. Moreover, these talented students rarely spent more than one year in Hong Kong, quickly jumping to graduate programs in the West and leaving Hong Kong academics without assistance for their laboratory or research work. Several universities proposed a program to the MOE in Beijing whereby university departments in Hong Kong would provide a number of slots for matriculating undergraduate students from top mainland departments, and the mainland departments would pre-select students from among their top five percent to send to Hong Kong; since these students were so good, their paperwork could begin before they completed their final term. But once nominated, these students could not submit early applications to any other university in the world. Also under the scheme, HKUST's departments could not reject the nominees, since once the mainland students committed to Hong Kong, they could not apply elsewhere.
This program was controversial; some faculty members felt that universities, not bureaucrats on the mainland, should select a school's graduate students. Departments in the Social Sciences worried that only politically correct students would be selected for this program. ${ }^{(39)}$ Also, graduate fellowships in Hong Kong at that time paid over HKD 15,000 a month, three times a mainland professor's salary; allowing mainland officials to control access to so much money would invite influence peddling. Finally, mainland students would lose their freedom of choice if they had to apply to only one place.

However, the climate on university campuses disliked views that disparaged or undermined links to the mainland. One division that joined the scheme had received assurances that it could reject candidates; but once it tried to do so, it was forced by a vice president to accept several students it had decided to reject. Another division that refused to join the program was publicly accused by its university president of being "anticommunist" - not a good label in 1997. The department replaced the postgraduate coordinator, but the following year the division insisted that mainland departments propose five students to be interviewed, from whom the department could select one. In fact, one faculty member travelled to Peking University to make the selection. However, with so much antipathy throughout Hong Kong's universities, the program was discontinued after two years.

\section{Changing views about mainland students in Hong Kong}

In the wake of the 1997 East Asian Financial Crisis and a government cut in financial support for education, Hong Kong universities developed many self-financed programs. But with demand in Hong Kong limited, and as increasing household wealth on the mainland drove demand for higher education, Hong Kong universities looked to the mainland for a new paying clientele. As Shive noted, "There has been a subtle shift from an attitude of

37. It was only in 1998, in honour of Peking University's 100th anniversary, that former Chinese President Jiang Zemin raised the slogan of creating "world class universities," and promised the funds to meet that challenge.

38. As of 1997, approximately 26 percent of all mainland students going into a graduate program were entering overseas universities. David Zweig, Internationalizing China: Domestic interests and global linkages, Ithaca (NY), Cornell University Press, 2002, p. 177.

39. A letter of recommendation from the Politics Department at Xiamen University stated that although the student's "theoretical" ability" (lilun shang) was not strong, he had terrific "organisational" (zuzhi) skills. Such "class leaders" would not necessarily make the most open-minded social scientists. 
Table for Figure 1 - Number of mainland students in Hong Kong, 2001-2010

\begin{tabular}{|l|c|c|c|c|c|c|c|c|c|c|c|c|}
\hline Types of Study & $2001-02$ & $2002-03$ & $2003-04$ & $2004-05$ & $2005-06$ & $2006-07$ & $2007-08$ & $2008-09$ & $2009-10$ & TOTAL \\
\hline Undergraduate (UG) & $536(24 \%)$ & $633(29 \%)$ & $842(34 \%)$ & $1284(39 \%)$ & $2007(47 \%)$ & $2973(52 \%)$ & $3658(54 \%)$ & $4348(56 \%)$ & $4562(54 \%)$ & $20843(48 \%)$ \\
\hline Taught Postgraduate (TPG) & $241(11 \%)$ & $101(5 \%)$ & $121(5 \%)$ & $63(2 \%)$ & $50(1 \%)$ & $55(2 \%)$ & $55(1 \%)$ & $39(1 \%)$ & $35(1 \%)$ & $760(2 \%)$ \\
\hline Research Postgraduate (RPG) & $1469(65 \%)$ & $1459(67 \%)$ & $1547(62 \%)$ & $1972(59 \%)$ & $2254(52 \%)$ & $2693(47 \%)$ & $3018(45 \%)$ & $3324(43 \%)$ & $3830(45 \%)$ & $21566(50 \%)$ \\
\hline TOTAL & 2246 & 2193 & 2510 & 3319 & 4311 & 5721 & 6731 & 7711 & 8427 & 43169 \\
\hline
\end{tabular}

Figure 1 - Mainland students in Hong Kong, 2001-2010

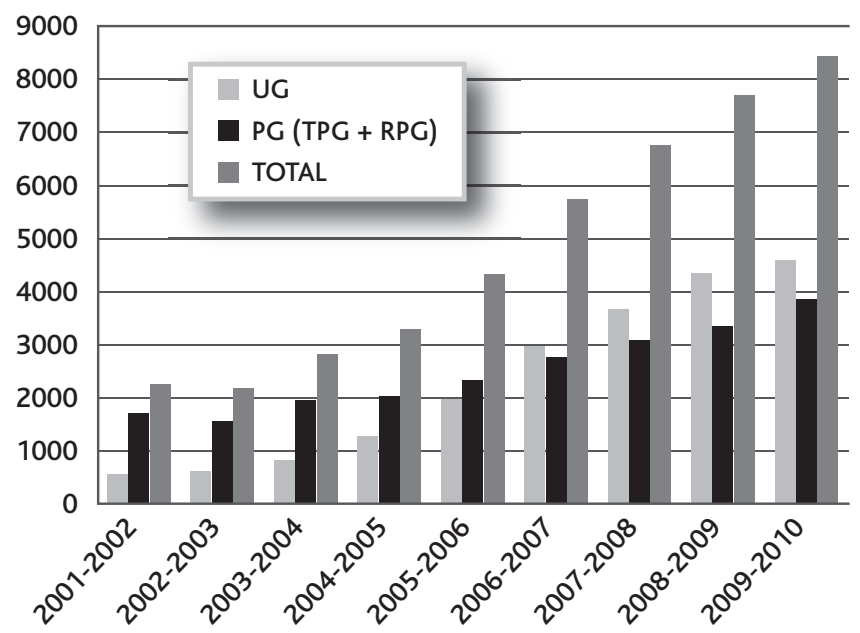

Source: http://cdcf.ugc.edu.hk/cdcf/searchStatisticReport.do (consulted on 12 October 2012), various years.

Notes: UG = Undergraduate; TPG = Taught Post-Graduate students, as oppossed to RPGs, who are Research Post-Graduate students. All RPGs in Hong Kong get full financial support.This figure only includes TPGs funded by the University Grants Council, so the actual number of TPGs might be much larger. Only the data for 2001-2002 include all non-local students, including those not from the mainland, but in those days there were very few non-local students who were not from the mainland.

'find the best talent in China and Hong Kong will pay' to 'find good talent in China who can also pay' to come to Hong Kong to study at university." (40)

Demand among mainland students to study in Hong Kong increased dramatically after 2002, and particularly after September 2005, when Hong Kong's new immigration policy allowed mainland students to stay on after graduation. The government also lifted the quota on mainland students in graduate programs and increased the share of "non-local" undergraduate students from 2 percent in 2002 to 10 percent in 2005. The response was immediate - in 2006, 50,000 students applied for 1,400 positions. ${ }^{(41)}$ The government in Beijing also approved a new policy allowing Hong Kong and Macau universities to recruit self-paying students from the mainland. To attract outstanding students from China, Hong Kong universities offer dozens of scholarships every year, and after graduation, mainland students can enter post-graduate (PC) programs or work in Hong Kong, becoming permanent residents after seven years.

Hong Kong PG programs have been an excellent springboard for mainlanders to pursue further studies overseas. Hong Kong professors with PhDs from top overseas universities can recommend mainland students to world class schools. In 2010, mainland students comprised 40-80 percent of Hong Kong's PG students, depending on the university, and among the 10,000 mainland students in Hong Kong universities, half are in PG programs.
What are the benefits of studying in Hong Kong over going overseas? Does an education in Hong Kong translate into a job back on the mainland? Do mainland students recommend that others study in Hong Kong? Answers to these questions help us assess Hong Kong's role as a training centre for a new generation of mainland students.

In Hong Kong, mainland students can get an international education in English, yet stay close to families, friends, and fiancés. While one report in 2007 stated that only 2 percent of mainland students in Hong Kong return to the mainland, ${ }^{(42)}$ interviews with mainland students at Hong Kong University of Science and Technology (HKUST) in 2009 suggested that after receiving a Master's degree, about one-third of students planned to go abroad for a PhD, one-third planned to remain in Hong Kong, and one-third planned to return to the mainland. For the first group, Hong Kong remains a "springboard" to the West, while the second cohort adopts a migration strategy that emerged after the Hong Kong government liberalised its migration policies. ${ }^{(43)}$

\section{Mainland student who returned from Hong Kong: A survey}

To assess Hong Kong's role in training Chinese students who return to the mainland, the Chinese Service Center for Scholarly Exchange (CSCSE) under the MOE carried out a survey with the support of the Center on China's Transnational Relations (CCTR) at HKUST. The CSCSE has the best list of returnees on the mainland, as many returnees need the CSCSE to certify their educational credentials. Thus they have the returnees' original addresses. In 2007, a research team from the CSCSE tried to contact all returnees from Hong Kong on their list - about 2,000 names. After finding 1,000 of them, the CSCSE sent them a self-administered survey with a return postage envelope. In the end, the CSCSE received 218 completed files (a 22 percent response rate). This section of the paper analyses the data from that survey.

\section{Characteristics of the sample population}

The average age was 30.5 years, with 40 percent between 25 and 29, and 35 percent between 30 and 34 . Fifty-six percent held an MA, while 39.5 percent held PhDs, suggesting that they will have a major role in the education and scientific research sectors on the mainland (Table 3). The ma-

40. Glenn Shive, "Mainland Students in Hong Kong Universities: New Visa Policies Will Help Hong Kong Become a Regional Hub for Higher Education," AmCham, September 2005, p. 28.

41. The annual intake remains around 1,400 students. Xinhua News Agency, "Hong Kong universities recruit over 1,400 mainland students," Hong Kong, 21 July 2010, http://news.xinhuanet.com/english2010/china/2010-07/21/c_13408010.htm (consulted on 11 October 2011).

42. " 2 percent Mainland Graduates Return from HK," Jiang Zhenying's Chinese Scholars Update, August 2007.

43. Mazzarol and Soutar found that an intention to migrate after graduation is a key motivating factor of overseas study. T. Mazzarol and G. N. Soutar, The Global Market for Higher Education, Chelthenham, Edward Elgar, 2001. 
Table 3 - Characteristics of the returnees in our survey

\begin{tabular}{|c|c|c|}
\hline Highest Degree Attained & & Percent \\
\hline Undergraduate & & 3.6 \\
\hline MA & & 56.4 \\
\hline PhD & & 39.6 \\
\hline \multicolumn{3}{|l|}{ Gender } \\
\hline Male & & 48 \\
\hline Female & & 52 \\
\hline \multicolumn{3}{|l|}{ Source of Funding } \\
\hline a. Chinese side gave full fellowship & & 4.3 \\
\hline b. HK gave full fellowship & & 59.1 \\
\hline c. HK gave partial fellowship & & 4.3 \\
\hline d. Totally relied on parents & & 20.7 \\
\hline e. Relied on themselves, but worked to help cover costs & & 2.9 \\
\hline f. Parents and student covered costs & & 8.2 \\
\hline g. Other & & 0.5 \\
\hline \multicolumn{3}{|l|}{ Work Experience Before Leaving China } \\
\hline a. Full or part-time work & & 43.8 \\
\hline b. No work experience & & 55.7 \\
\hline \multicolumn{3}{|l|}{ Satisfaction with Current Work } \\
\hline a. Very satisfied & & 12.3 \\
\hline b. Satisfied & & 38.4 \\
\hline c. Average & & 35.2 \\
\hline d. Relatively unsatisfied & & 13.2 \\
\hline e.Very unsatisfied & & 0.5 \\
\hline College Attended & Number & Percent \\
\hline a. HKU & 51 & 23.2 \\
\hline b. CUHK & 31 & 14.6 \\
\hline c. HKUST & 30 & 13.6 \\
\hline d. City University & 36 & 16.4 \\
\hline e. Baptist University & 19 & 8.6 \\
\hline f. Lingnan University & 3 & 1.4 \\
\hline g. Poly University & 45 & 20.5 \\
\hline h. Shue Yan University & 3 & 1.4 \\
\hline \multicolumn{3}{|l|}{ Marital Status } \\
\hline a. Married & & 55 \\
\hline b. Single & & 43.6 \\
\hline c. Other & & 1.4 \\
\hline \multicolumn{3}{|l|}{ Work Experience in Hong Kong } \\
\hline a. Full-time & & 14.2 \\
\hline b. Part-time & & 9.6 \\
\hline c. No work experience & & 75.8 \\
\hline \multicolumn{3}{|l|}{ Returned to Original Unit } \\
\hline a. Yes & & 25.5 \\
\hline b. No & & 65.7 \\
\hline c. No response & & 8.8 \\
\hline \multicolumn{3}{|l|}{ Family Background } \\
\hline a. High Ranking Cadre & & 0.5 \\
\hline b. Middle level cadre & & 21.7 \\
\hline c. Worker & & 23 \\
\hline d. Peasant & & 14.8 \\
\hline e. Intellectual & & 32.7 \\
\hline f. Small business family & & 3.2 \\
\hline g. Private enterprise & & 1.8 \\
\hline h. Military & & 0.5 \\
\hline i. Other & & 1.8 \\
\hline
\end{tabular}

\begin{tabular}{|c|c|}
\hline Specialisation & Percent \\
\hline a. Chinese medicine & 1 \\
\hline b. Western medicine & 4.4 \\
\hline c. Engineering/applied science & 25.1 \\
\hline d. Law & 12.1 \\
\hline e. Natural science & 13.5 \\
\hline f. Business and management & 23.2 \\
\hline g. Socials science \& humanities & 7.2 \\
\hline h. Arts and humanities & 12.6 \\
\hline
\end{tabular}

Source: Survey by CSCSE, 2007.

Note: $\mathrm{N}=\mathbf{2 1 8}$

jority - 77 percent - had returned since 2005 , with 35 percent returning in 2006, 24 percent in 2007 and 18 percent in 2005. ${ }^{(44)}$ As fresh returnees, they are just beginning to find their way professionally on the mainland. Women comprise 52 percent, while 55 percent of the group are married. As for social background, 21.7 percent are children of middle-level cadres, 32.7 percent come from intellectual households, and 5 percent have parents who run their own businesses. ${ }^{(45)}$ Many are children of peasants (14.8 percent) and workers (23 percent), demonstrating social mobility.

Other key characteristics that affect their lives after they return to the mainland include: 56 percent had not held a job on the mainland before going to Hong Kong, and only 14.2 percent had worked full time in Hong Kong before returning, complicating their job search on the mainland. Limited work experience in Hong Kong means that little of Hong Kong's professional work ethic was transferred, although mainland students already work harder than most Hong Kongers. Also, 56.4 percent were members of a political party - so at least 50 percent were CCP members - which reflects the recent recruitment efforts of the CCP on college campuses.

A plurality of returnees settled in Beijing, and over half settled in Beijing or Shanghai (Table 4). While we do not know where they were born, they have been able to settle in China's most popular destinations. Also, 27 percent of the group settled in the Pearl River Delta of Guangdong Province and its capital of Guangzhou, reflecting the academic links between Guangdong and Hong Kong.

\section{Contributions to the mainland}

One of Hong Kong's biggest contribution to these mainland students is that its universities gave 60 percent of them a full scholarship, while 4.3 percent received partial funding - a very significant contribution to the education of China's future elite. Comparatively, only 31 percent of Chinese students who returned from Japan and registered with the CSCSE in Beijing received a free ride from Japan's government or universities. ${ }^{(46)}$ Of mainland students in Hong Kong, 21 percent relied totally on their parents, and 8.2 percent shared the cost with their parents.

44. Those who registered with the CSCSE in earlier years had probably moved by the time we did our survey; thus most respondents were recent returnees, biasing our sample somewhat.

45. For a detailed study of the implications of the social class of mainland students in Hong Kong, see Mei Li and Mark Bray, "Social Class and Cross - Border Higher Education: Mainland Chinese Students in Hong Kong and Macau," Journal of International Migration and Integration, Vol. 7, No. 4, Fall 2006, pp. 407-24.

46. Han Donglin and David Zweig, "Guoji yiminde kuaguo lianxi: liyu liu ri hai gui de shizheng yanjiu," (International migrants' transnational relationship: Based on empirical research about returnees from Japan), Guoji guancha (International Observer), Vol. 5, No. 113, 2011, pp. 67-74. 
Table 4 - Regional distribution of returnees from Hong Kong, percentages

\begin{tabular}{|l|c|l|l|}
\multicolumn{1}{c|}{ City } & \multicolumn{2}{c|}{ Percent } & \multicolumn{2}{c|}{ City } & \multicolumn{2}{c|}{ Percent } \\
\hline Beijing & $31(26)$ & Xi'an & $1.8(4)$ \\
\hline Shanghai & $21(14)$ & Hangzhou & $4.1(8)$ \\
\hline Shenzhen & $16(11)$ & Jinan & $2.3(3)$ \\
\hline Guangzhou & $11(13)$ & Nanjing & $2.3(3)$ \\
\hline Tianjin & $2.7(4)$ & Others & $7.8(14)$ \\
\hline
\end{tabular}

Source: Survey by CSCSE, 2007.

Note: Scores in parenthesis are the percent of the total in academic or scientific institutions, while those outside the parenthesis reflect those in the workforce.

\section{The role of the different universities}

Mainland students are distributed widely among Hong Kong universities, with a surprising number attending the Polytechnic University (Table 3), as PolyU quickly and aggressively established mainland ties. School selection is linked to their specialisation. Hong Kong University (HKU) enrols the largest number of students (23.2 percent), aided by its Law School, which enrols 30 percent of HKU's mainland students. At HKUST, 44 percent of mainland students studied engineering and applied sciences. PolyU had mostly engineering (41 percent) and natural science students (36 percent). Overall, HKU had the widest distribution of students, with enrolment in all subjects but Chinese medicine.

Funding varied by university (Table 5). The MOE only funds students going to HKU, surprising given the university's colonial heritage. Of the 123 students with full funding, 64 percent attend Hong Kong's three research universities - Chinese University of Hong Kong (CUHK), HKUST, and HKU. And among these schools, HKUST gives a free ride to 86 percent of its mainland students, CUHK gives full or partial support to 77 percent, and HKU gives full or partial tuition to 71 percent of its mainland students. ${ }^{(47)}$ Again, PolyU funds students at a comparable level, giving full or partial support to 63 percent of its mainland students, while Hong Kong Baptist University (HKBU) and City University fund less than half of their mainland students. Clearly, HKBU and City U get income from these mainland students, whose families can afford to send them outside of the mainland.

The students being trained in Hong Kong are of high quality. We ranked the mainland universities that our returnees attended before entering graduate school in HK on a scale from 1 to 7 , and then looked at the quality of enrolment by Hong Kong universities (Table 6). HKUST gets the best students, followed by HKU, with both getting over half their students from the top 12 universities on the mainland - quite a select group. CUHK does not do as well as one might expect, while despite its willingness to spend money, PolyU is not attracting as good students as HKBU, which is making more of them pay their own way.

\section{The benefits of studying in Hong Kong}

Did returnees see their education in the territory as beneficial to their careers? We can also assess HK's contribution by looking at what they felt they learned and whether the job search was difficult when they returned.

When we asked people about the utility of studying in Hong Kong, 58 percent felt that they could "learn a new technology or research methodology which they could bring back to the mainland." This response supports the argument that returnees seek a "shortage good" available in the West outside of China that enhances their opportunities upon their return, creating "comparative advantage," which therefore encourages reverse migration. ${ }^{(48)}$ Other useful aspects of Hong Kong include: "improving their chance to get a job in a foreign or Hong Kong company" (17.8 percent), or "they can get special benefits when they return" (10.7 percent). In other words, they went out to get more upon their return.

Of 14 suggested reasons as to why they selected Hong Kong over going overseas, the top six choices comprise over 80 percent of the reasons selected. Responses highlight two aspects of studying in Hong Kong: (1) its mix of Western and Chinese culture and education, and (2) its geographic proximity to the mainland. ${ }^{(49)}$ Hong Kong offers mainlanders a window on the world within a Chinese environment. Thus, 15.8 percent said that in Hong Kong they "could get a Western education in a Chinese cultural environment," 18.9 percent said that in Hong Kong they could understand the integration of Western and Chinese culture, while 15.2 percent said that in Hong Kong they could get international information easily.

These young people also want to be near family, friends, and China. Particularly for students from Guangdong Province, Hong Kong's geographic location is a strong incentive to study there. Some even appreciated that they could get a Western education while still working for their home unit. Their reasons for returning suggest that many who selected Hong Kong wanted to stay close to home. When asked why they returned to China, 10.5 percent felt a responsibility to care for their parents, while 12.7 percent said that their spouse or girl/boyfriend wanted them to come home.

\section{Evaluating the Hong Kong experience}

Among our returnees from Hong Kong in academia or research, 40 percent saw the primary benefit as making it possible to publish in international journals. With mainland universities competing furiously for international status, having mastered the art of publishing overseas enhances a returnee's "transnational capital." (50) Similarly, studying in Hong Kong improved their academic competitiveness in China (20.4 percent), raised their academic status (17.9 percent), and increased student interest in their courses (14.5 percent). These answers reflect important individual benefits of studying in Hong Kong (but also the benefits of studying abroad in general).

Studying in Hong Kong can enhance the job search on the mainland, which can be measured by the job search experience. While we cannot compare this group's experience to students who graduated in the mainland, we can present our respondents' objective and subjective feelings about their job search, and compare their experience to returnees from other countries.

47. In her 2002-2003 survey, Li Mei found that 97.7 percent of mainland students received scholarships, but these were almost all graduate students, who at that time could not come to Hong Kong without funding from the university. Mei Li and Mark Bray, "Cross Border Flows of Students for Higher Education: Push-pull Factors and Motivations of Mainland Chinese Students in Hong Kong and Macau," Higher Education, Vol. 53, No. 6, 2007, pp. 803-04.

48. David Zweig, Chung Siu Fung, and Wilfried Vanhonacker, "Rewards of Technology: Explaining China's Reverse Migration," Journal of International Migration and Integration, Vol. 7, No. 4, November 2006, pp. 1-33.

49. In addition to the mix of East and West and geographic proximity, Li and Bray also found "cultural identity" and fellowships as important reasons for mainlanders to study in Hong Kong. Li and Bray, "Cross Border Flows," art. cit., p. 806.

50. David Zweig, Stanley Rosen, and Chen Changgui, "Globalization and transnational human capital: Overseas and returnee scholars to China," The China Quarterly, Vol. 179, September 2004, pp. 735757 
Table 5 - Level of support for mainland students at HK Universities, by HK Universities

\begin{tabular}{|l|c|c|c|c|c|c|c|c|} 
& CUHK & HKU & HKUST & HKBU & City U & Lingnan & Poly U \\
\hline Full mainland government funding & 0 & $18.40 \%$ & 0 & 0 & 0 & 0 & 0 \\
\hline Full HK scholarship & $76.70 \%$ & $63.30 \%$ & $82.10 \%$ & $42.10 \%$ & $41.20 \%$ & $33.30 \%$ & $54.80 \%$ \\
\hline Partial HK scholarship & 0 & $6.10 \%$ & $3.60 \%$ & 0 & $5.90 \%$ & 0 & $7.10 \%$ \\
\hline Complete reliance on parents & $16.70 \%$ & $8.20 \%$ & $7.10 \%$ & $42.10 \%$ & $41.20 \%$ & $33.30 \%$ & $21.40 \%$ \\
\hline Self reliant - part work, part study & 0 & $2.00 \%$ & 0 & 0 & $5.90 \%$ & 0 & $2.40 \%$ \\
\hline Parents/student pay & $6.70 \%$ & $2.00 \%$ & $7.10 \%$ & $15.80 \%$ & $5.90 \%$ & 0 & $11.90 \%$ \\
\hline
\end{tabular}

Source: Survey by CSCSE, 2007.

Note: $\mathrm{N}=218$

Table 6 - Quantity and quality of mainland students, by HK universities

\begin{tabular}{|c|c|c|c|c|c|c|c|c|}
$\begin{array}{c}\text { Rank of } \\
\text { mainland college }\end{array}$ & CUHK & HKU & \multicolumn{1}{c}{ HKUST } & HKBU & City U & $\begin{array}{c}\text { Lingnan } \\
\text { Poly U }\end{array}$ & $\begin{array}{c}\text { Cumulative } \\
\text { Average }\end{array}$ \\
\hline $1-2$ & $6.50 \%$ & $15.70 \%$ & $13.30 \%$ & $10.50 \%$ & 0 & 0 & $11.10 \%$ & $10.70 \%$ \\
\hline $3-6$ & $12.90 \%$ & $27.50 \%$ & $36.70 \%$ & $15.80 \%$ & $11.10 \%$ & 0 & $15.60 \%$ & $21.90 \%$ \\
\hline $7-12$ & $32.30 \%$ & $52.90 \%$ & $53.30 \%$ & $26.30 \%$ & $16.70 \%$ & 0 & $20.00 \%$ & $37.20 \%$ \\
\hline $13-25$ & $51.60 \%$ & $62.70 \%$ & $70.00 \%$ & $42.10 \%$ & $30.60 \%$ & $33.30 \%$ & $33.30 \%$ & $53.10 \%$ \\
\hline $26-50$ & $61.30 \%$ & $74.50 \%$ & $76.70 \%$ & $52.60 \%$ & $50.00 \%$ & 0 & $42.20 \%$ & $66.80 \%$ \\
\hline $51-150$ & $64.50 \%$ & $92.20 \%$ & $83.30 \%$ & $57.90 \%$ & $66.70 \%$ & 0 & $55.60 \%$ & $79.60 \%$ \\
\hline $150-500$ & $83.90 \%$ & $96.10 \%$ & $90.00 \%$ & $94.70 \%$ & $86.10 \%$ & $66.70 \%$ & $91.10 \%$ & $100 \%$ \\
\hline Total No. & 31 & 51 & 30 & 19 & 36 & 3 & 45 & \\
\hline
\end{tabular}

Source: http://rank2007.netbig.com/cn/rnk_1_0_0.htm (consulted on 12 October 2012).

Note: Numbers in the table are cumulative percentages.

Table 7 - Why study in Hong Kong (as compared to elsewhere)?

\begin{tabular}{|c|c|c|c|c|}
\hline Reason & $\begin{array}{l}\text { First } \\
\text { Choice }\end{array}$ & $\begin{array}{l}\text { Second } \\
\text { Choice }\end{array}$ & $\begin{array}{l}\text { Third } \\
\text { Choice }\end{array}$ & $\begin{array}{l}\text { Adjusted } \\
\text { Score }\end{array}$ \\
\hline 1. Can understand the integration of Western and Chinese culture & 35 & 51 & 21 & $349(19.0 \%)$ \\
\hline 2. Get a Western education in a Chinese environment & 48 & 11 & 19 & $292(15.9 \%)$ \\
\hline 3. Convenient to get international information & 29 & 37 & 25 & $281(15.3 \%)$ \\
\hline 4. Hong Kong is a "foreign outpost near home" & 35 & 27 & 16 & $272(14.8 \%)$ \\
\hline 5. Hong Kong gives good scholarships & 18 & 23 & 27 & $186(10.1 \%)$ \\
\hline 6. Get a Western education while still working for their home unit & 16 & 4 & 3 & $95(5.2 \%)$ \\
\hline Total & 181 & 153 & 111 & \\
\hline
\end{tabular}

Source: CSCSE Survey, 2007.

Note: Adjusted Score: First Choice $=5$, Second Choice $=3$, Third Choice $=1$.

We asked returnees both about the difficulty experienced finding a job (subjective measures) and the time spent finding a job (objective measure). Overall, these returnees did not experience too much difficulty finding work on the mainland. On a 5-point scale, running from "not difficult at all" to "extremely difficult," 40.2 percent reported "no difficulty at all," while another 27 percent, who selected the next option, could be said to have experienced "little difficulty." Those in the bottom two categories, who would have found the job search "extremely difficult" or "difficult," totalled 12.7 percent.

The objective measure - the actual amount of time it took to find a job after returning - matches their subjective evaluations. Table 6 shows that 78.3 percent would not be classified as unemployed by the ILO's criteria, (51) and by six months, 94 percent had a job. Compared to returnees from Japan and Canada in our other surveys, ${ }^{(52)}$ returnees from Hong Kong were much more successful than returnees from Canada in arranging jobs before re-

51. According to the International Labour Organization, someone is not "unemployed" unless they cannot find a job for over three months.

52. The results of those surveys were published in two reports: David Zweig, "A Limited Engagement: Mainland Returnees from Canada," Research Report, Asia-Pacific Foundation of Canada, 19 December 2008, www.asiapacific.ca/fr/research-report/limited-engagement-mainland-returneescanada (consulted on 20 September 2012); and David Zweig and Han Donglin, The Role of Mainland Students and Trainees in Sino-Japanese Relations: A Preliminary Report, Center on China's Transnational Relations - Working Paper No. 16, HKUST, 2006. Both surveys were carried out in collaboration with Chinese Service Center for Scholarly Exchange (CSCSE), Ministry of Education (Beijing). 
Table 8 -Time used finding a job: results from three surveys

\begin{tabular}{|l|c|c|c|}
\hline Time to find a job & Returnees from HK & Returnees from Japan & Returnees from Canada \\
\hline Arranged before returning & $53.50 \%$ & $51.70 \%$ & $25.70 \%$ \\
\hline Under 3 months & $24.9 \%(78.3 \%)$ & $28.4 \%(80.1 \%)$ & $47 \%(72.7 \%)$ \\
\hline 3-6 months & $16.1 \%(94.5 \%)$ & $1.2 \%(92.3 \%)$ & $20.3 \%(93.0 \%)$ \\
\hline More than 6 months & $1.8 \%(100 \%)$ & $7.7 \%(100 \%)$ & $7.0 \%(100 \%)$ \\
\hline
\end{tabular}

Source: CSCSE Survey, 2007.

Note: Scores in the bracket are the cumulative percentage.

Table 9 - Explaining the perceived difficulty of finding a job on the mainland (54)

\begin{tabular}{|l|c|c|c|c|c|}
\hline & \multicolumn{2}{|c}{$\begin{array}{c}\text { Unstandardised } \\
\text { Coefficients }\end{array}$} & $\begin{array}{c}\text { Standardised } \\
\text { Coefficients }\end{array}$ & T & Sig. \\
\hline (Constant) & B & Std. Error & Beta & -0.561 & 0.576 \\
\hline Gender & -1.099 & 1.958 & & 0.917 & 0.361 \\
\hline Age & 0.169 & 0.184 & 0.075 & 0.917 \\
\hline Mode of study & 0.03 & 0.022 & 0.136 & 1.354 & 0.178 \\
\hline Source of funding & 0.619 & 0.209 & 0.243 & 2.961 & $.004^{* * *}$ \\
\hline Marital status & -0.008 & 0.011 & -0.062 & -0.756 & 0.451 \\
\hline 1st reason for studying in HK & 0.314 & 0.179 & 0.152 & 1.75 & $.083^{*}$ \\
\hline 2nd reason to study in HK & -0.114 & 0.06 & -0.153 & -1.911 & $.058^{*}$ \\
\hline Full or part-time job in HK before returning & -0.053 & 0.047 & -0.089 & -1.116 & 0.267 \\
\hline Returned to former company & -0.058 & 0.135 & -0.036 & -0.434 & 0.665 \\
\hline Length of time finding a job & 0.008 & 0.004 & 0.154 & 1.772 & $.079^{*}$ \\
\hline Satisfied with current job & 0.528 & 0.107 & 0.408 & 4.93 & $.000^{* * *}$ \\
\hline Last month's salary in HK & 0.255 & 0.106 & 0.198 & 2.395 & $.018^{* *}$ \\
\hline Highest degree & -0.009 & 0.004 & -0.177 & -2.023 & $.045^{* *}$ \\
\hline Specialisation in HK & 0.102 & 0.205 & 0.05 & 0.501 & 0.617 \\
\hline Length of time living in HK & -0.004 & 0.011 & -0.031 & -0.37 & 0.712 \\
\hline Year returned to mainland & 0.008 & 0.032 & 0.02 & 0.252 & 0.802 \\
\hline Encourage others to study in HK & -5 & 0.001 & 0.004 & 0.039 & 0.969 \\
\hline
\end{tabular}

Source: CSCSE Survey, 2007

Notes: Mode of study involves self-paying, government funded, or support from their home unit. $p<.10=*, p<.05=* *, p<.01={ }^{* * *}$

turning home, but there was very little difference between the Hong Kong and Japan cohorts. Relative to going to Japan, studying in Hong Kong did not ease the job search experience, but it did relative to students in Canada. ${ }^{(53)}$

Multivariate analysis discovers the most relevant factors that influence the job search. First, the higher their last month's salary in Hong Kong, the easier was their job search on the mainland (Table 9). This finding reinforces the argument that returnees are best prepared if they work full time overseas before returning. However, only recently has the Hong Kong government made it easier for mainland students who graduate in Hong Kong to work in the territory before returning to the mainland.

Mode of study was important largely because those who came to Hong Kong with the support of their home unit could return to their job, thereby avoiding any job search. The fact that people's "first" and "second" reason for coming to Hong Kong correlates with their perceived difficulty in finding a job suggests that many returnees had adopted a good strategy in coming to Hong Kong. The findings also suggest that those who came prepared to learn a new skill and succeeded in doing so found a job upon returning more easily, again mirroring the "shortage good" hypothesis.

When asked whether their Hong Kong experience was important for their work on the mainland, 29.8 percent said that the Hong Kong experience was "extremely important," while another 37.6 percent selected the second point on a five-point scale. Thus, over two-thirds see their HK experience as important to their work on the mainland; only 6.5 percent see it as "not very important" or "not important at all." When asked specifically how they benefitted from their time in Hong Kong, 24.3 percent pinpointed research ability, 19.6 percent selected teaching ability, 19.1 percent appreciated the greater access to information, while 17.9 percent felt that studying in Hong Kong had strengthened their competitiveness. Yet, they were not so enthralled with the overall experience, as only 18.2 percent would "strongly encourage" others to go to Hong Kong to work or study, with the vast majority (72.3 percent) simply saying that they would "recommend" others to

53. Over 25 percent of returnees from Japan in our 2006 survey found jobs in Japanese companies in China due to their Japanese language skills. But as with returnees from Canada, English language facility is not such a comparative advantage. 
Table 10 - Following HK educational norms on the mainland, among academics for whom the systems differ

Do you follow HK educational norms? Frequency

Percent

Cumulative

\begin{tabular}{|l|c|c|c|}
\hline 1 (Totally follow HK educational norms) & 4 & 7.4 & 7.4 \\
\hline 2 & 27 & 50.0 & 57.4 \\
\hline 3 & 14 & 25.9 & 83.3 \\
\hline 4 & 3 & 5.6 & 88.9 \\
\hline 5 (Do not follow HK norms at all) & 1 & 1.9 & 90.7 \\
\hline No response & 5 & 9.4 & 100 \\
\hline Total & 54 & 100 & \\
\hline
\end{tabular}

Table 11 - How does studying in HK affect returnees' values?

\begin{tabular}{|c|c|c|c|c|}
\hline Type of Change & $\begin{array}{c}\text { First } \\
\text { Aspect }\end{array}$ & $\begin{array}{l}\text { Second } \\
\text { Aspect }\end{array}$ & $\begin{array}{c}\text { Third } \\
\text { Aspect }\end{array}$ & $\begin{array}{l}\text { Adjusted } \\
\text { Score }\end{array}$ \\
\hline Support for academic freedom & 36 & 10 & 13 & $223(23.8 \%)$ \\
\hline Scientific research methodology & 24 & 18 & 11 & $185(19.7 \%)$ \\
\hline Independence in doing research & 16 & 17 & 13 & $144(15.4 \%)$ \\
\hline Equality in competition for research funds & 9 & 15 & 6 & $96(10.2 \%)$ \\
\hline Intellectual property & 9 & 11 & 6 & $84(9.0 \%)$ \\
\hline Equal relations between professors and students & 7 & 9 & 15 & $77(8.2 \%)$ \\
\hline Fairness in promotion system & 3 & 11 & 7 & $55(5.9 \%)$ \\
\hline Blind refereeing & 4 & 5 & 11 & $46(4.9 \%)$ \\
\hline Professors in HK don't take credit for students' successes & 2 & 2 & 5 & $21(2.2 \%)$ \\
\hline
\end{tabular}

Source: CSCSE Survey, 2007

Notes: Adjusted Score: First Choice = 5, Second Choice $=3$, Third Choice $=1$.

go to HK. Finally, 8.2 percent would "not so strongly recommend others to go to Hong Kong" (bu tai tuijian).

\section{One country, two value systems?}

A major hypothesis driving this research is the assumption that studying abroad can influence the value system of sojourners. Returnees from Japan and Canada had more liberal views of the international system and China's place in it, relative to members of China's middle class who had not been abroad. (55) But do returnees internalise Hong Kong's open and transparent academic norms and introduce them into the mainland? Are these people a vehicle for introducing new values into the mainland?

We asked returnees to compare Hong Kong's and the mainland's academic value system (jiazhiguan). Among respondents, 53 percent saw the value systems as "totally" or "rather different," while 13 percent felt that the two systems were "totally" or "relatively" the same. Among those who saw differences between the systems (Table 10), 57.4 percent say they follow Hong Kong's style in research and teaching on the mainland. Of note, only 4/54 (7.5 percent) "totally follow" Western norms, showing that pressures to fit in are powerful in China. Still, over half (31/54) are following and actively transferring values into China.

What were these values (Table 11)? Above all, they value "academic freedom" (23.8 percent), even though they did not emphasise this issue in an earlier question. They also changed their attitudes towards the scientific nature of scholarship or research methodology (19.7 percent). Mainland researchers often do research and interpret the data to prove their point, while the Western tradition sees the rejection of hypotheses as advancing the analysis. Returnees emphasise "independence in doing research" (15.4 percent) - though whether this means independence from their supervisor is unclear - as well as equality in the competition for research funds (10.2 percent). (56) Finally, returnees value "intellectual property" (9 percent), the equality of relations between a professor and his student, fairness of the promotion system (6 percent), blind referring ( 5 percent), and not having the fruits of their work stolen by professors.

\section{Conclusion}

Hong Kong has contributed in diverse ways to the development of educational institutions on the mainland. It has sent leading academics and professionals into mainland universities, in some case revolutionising the curriculum and programs there with significant success. Risk taking, innovation, and deep pockets all help this process of engagement. Second, Hong Kong's universities have used their wealth and international links to attract top students from China, creating a growing cohort of Hong Kong-trained scholars, professionals, and students; still, their numbers have been surprisingly small due to Hong Kong's previous "closed shop"

54. While we did not include membership in the Chinese Communist Party in the multiple regression, the bivariate relationship between CCP membership and job search was highly significant at p. 3 .

55. Han Donglin and David Zweig, "Images of the World: Studying Abroad and Chinese Attitudes towards International Affairs," The China Quarterly, No. 202, June 2010, pp. 290-306.

56. This is a hot button issue today in the mainland's scientific community. See Yigong Shi and Yi Rao, "China's Research Culture," Science, Vol. 329, No. 5996, 3 September 2010, p. 1128. 
mentality and the difficulties of migrating to the SAR. Finally, many mainlanders trained abroad have settled in Hong Kong and shared research funding, findings, and new methodologies with their mainland colleagues.

Mainland students want to study in Hong Kong, though most still prefer top US and British universities, so Hong Kong's enunciated goal of becoming an "educational hub in East Asia" is achievable only if the Hong Kong government invests enough money in it. Not only can Hong Kong enhance its competitiveness with mainland cities, such as Shanghai and Beijing, by attracting, training, and keeping top students from these cities, but by inculcating Western academic values into mainland universities Hong Kong can narrow the normative gap between the two territories, ensure its own academic freedom, and improve the quality of academia on the mainland.

As integration with the mainland deepens, we anticipate far more Hong Kong involvement in the mainland, particularly in Guangdong Province, where the impact on universities in Zhuhai, Shantou, and Guangzhou has been greatest. As we saw, a high percentage of returnees to Guangzhou go into academia. But whether Hong Kong can significantly improve Guangdong's relatively weak academic institutions remains to be seen. Also, academics in Hong Kong are still pushed by their administrators to partner with top schools in Beijing, Shanghai, Nanjing, Xian, and Guangzhou.

Hong Kong's experience, particularly in running universities in China, has set an excellent precedent that others are quickly following. As mentioned above, Nottingham, Liverpool, and NYU are, or will soon be, running universities in China in collaboration with mainland universities. In any case, the links between Hong Kong and mainland universities are strong, helping Hong Kong enhance its role in academic development in China.

I Liu Mei Heung, Amy, is Deputy Chief Editor of the South China Morning Post, Chinese. She is an advisor to the Center on Environment, Energy and Resource Policy at The Hong Kong University of Science and Technology.

Morning Post Centre, 22 Dai Fat Street, Tai Po Industrial Estate, New Territories, Hong Kong (amyliuamyliu@yahoo.com).

I David Zweig is Associate Dean, School of Humanities and Social Science, Chair Professor, Division of Social Science, and Director, Center on Environment, Energy and Resource Policy, at The Hong Kong University of Science and Technology.

HKUST, Clearwater Bay, Kowloon, Hong Kong (sozweig@ust.hk). 